\title{
Basis Sector in the Economic Structure of Badung Regency, Bali, Indonesia
}

\author{
Made Antara $^{1, *}$, I.G.A. Oka Suryawardhani ${ }^{2} \&$ Ni Made Lodi Dwi Utami ${ }^{3}$ \\ ${ }^{1}$ Study Program of Agribusiness, Faculty of Agriculture, University of Udayana, Bali, \\ Indonesia \\ ${ }^{2}$ Study Program of Agribusiness, Faculty of Agriculture, University of Udayana, Bali, \\ Indonesia \\ ${ }^{3}$ Graduates of Study Program of Agribusiness, Faculty of Agriculture, University of Udayana, \\ Bali, Indonesia \\ *Correspondence: Study Program of Agribusiness, Faculty of Agriculture, University of \\ Udayana, Bali, Indonesia. E-mail: antara_unud@yahoo.com. Tel: 62-812-384-1814
}

Received: August 27, 2017 Accepted: September 19, $2017 \quad$ Published: September 27, 2017

doi: 10.5296/rae.v9i3.11759ＵRL: https://doi.org/10.5296/rae.v9i3.11759

\begin{abstract}
Badung is one of the tourism development centers in Bali with prominent tourism destinations are Kuta, Jimbaran and Nusa Dua. The development of tourism in Badung regency is rapidly causing inequality of regional development between north and south and the imbalance of development between economic sectors. So it is necessary to analyze the basis sectors in accordance with the potential of north and central region. The purpose of this study is to analyze the basis sectors in the economic structure of Badung Regency and to track the causative factors the change of the role of agriculture sub-sector using Shift Share analysis method. This study uses secondary data in the form of data of Gross Regional Domestic Product (GRDP) 2011-2016, like GRDP and Badung and Bali, and Growth rate GRDP. Data collection methods used was documentation method and data analyze using Static Location Quotient (LQ), Dynamic Location Quotient (DLQ), and Shift Share. The results of analysis showed that the basis sectors in economic structure of Badung Regency is water supply, waste, and recycling sector, construction sector, transportation and warehousing sector, and accommodation and feeding supply sector. The agricultural sub-sector has three sub-sub-sectors that are able to become the basis sub-subsector in the future are food crop sub-sub-sectors, horticultural crops sub-subsector, and fishery sub-sector. Two factors causing the change of agriculture, forestry and fishery sub-sector positions in the economic structure of Badung Regency, namely economic structure and location factor
\end{abstract}

Keywords: Basis Sector, Location Quotient, Dynamic Location Quotient, Shift Share 


\section{MlMacrothink}

\section{Introduction}

\subsection{Background}

The existence of natural resources and abundant human resources, making Indonesia as a country that has the potential to be developed in various sectors that are able to support national economic development. Economic development is usually associated with economic growth in developing countries, some economists such as Sukirno (2002) interpret economic development is growth plus change that is economic development is economic growth followed by changes in the structure and style of economic activity.

Economic development has four main dimensions, namely growth, poverty alleviation, economic change or transformation, and the sustainability of development from agrarian society to industrial society (Todaro, 1999). Good development can be known through regional economic growth that is by the demand of goods and services from outside the region, so that local resources are able to provide an increase to the local wealth and can create job opportunities in the region (Erawati, 2012). At the national level, economic growth is indicated by changes in Gross Domestic Product (GDP), while regionally can be seen from the changes that occur in Gross Regional Domestic Product (GRDP). GRDP is gross added value arising from all sectors of the economy in a region.

The regency of Badung is one of the nine regencies/cities in Bali Province with an area extending from north to south. Development in Badung regency is divided into three areas: North Badung (Abiansemal District and Petang District), Middle Badung (Mengwi District), and South Badung (North Kuta, Central Kuta, and South Kuta District). Each region has different potentials such as North Badung dominated by plantation activities, food crops, nature tourism, livestock, household handicraft, and nature conservation. Middle Badung is dominated by agricultural activities, livestock, cultural tourism as well as small industries and household handicrafts. South Badung is dominated by tourism, education, fisheries, small industry and trade and services (Badungkab, 2017).

Badung regency is the biggest contributor to the economy of the Province of Bali, because in Badung Regency located Ngurah Rai International Airport as the entrance and exit of tourists, and located many star and non star hotels, so the sector of providing accommodation and eating-drinking the largest contributor to GRDP of Badung Regency, on By 2015 by 28.55 percent. Compared with the contribution of the agricultural sector which is still mostly done by the people of North Badung and Middle Badung region only able to contribute 6.70 percent in 2015 and every year it decreases (CBS Badung, 2015).

Tourism is growing rapidly in the area of Southern Badung with tourist destinations are Kuta-Seminyak, Jimbaran and surrounding areas, and Nusa Dua, has created various economic activities related to tourism services, which is supporting the economy of Badung Regency. This condition allows the change of basis sector and the shifting of economic structure of Badung Regency. 


\subsection{Objectives of the Research}

The objectives of the research are to identify the basis sectors in the economic structure of Badung Regency, and the sub-sector in the agricultural sector in Badung Regency using LQ and DLQ analysis methods, and to track the factors causing the change of the role of agriculture sub-sector using Shift Share analysis method.

\section{Literature Review}

The theory of economic basis states that the main determinant of economic growth of a region is the demand for goods and services from other regions. Production processes in the industrial sector of an area using local production resources, including labor and raw materials, and outputs are exported will yield in economic growth, increased per capita income, and job creation in the region (Hoover, 1975; Bendavid-Val, 1991; Azis, 1994; Isard et al., 1998; Stimson et al., 2006; Armstrong and Taylor, 2007; Tambunan, 2001 in Hastutiningsih, 2010). The theory of economic basis clarifies all economic activities into two sectors: the basis sector and the non-basis sector.

Rusastra, et al., 2002 (in Hendayana, 2003) explains that basis activities are activities of a society whose outcomes are either goods or services intended for export out of a community environment or outward, regional, national and international oriented. While non-basis activity is a community activity that results either in the form of goods or services destined for the community itself in the area of economic life of the community. The theory of economic basis base his view that the economic growth rate of a region is determined by the large increase in exports from the region. In the regional economic sense (see: Richardon, 2001), exports are to sell products or services outside the territory either to other regions within the country or abroad. According to Tarigan, 2009 (in Hastutiningsih, 2010), economic activities are grouped on basis activities and nonbasis activities. Activity basis is an activity that is exogenous means not tied to the internal condition of the region's economy and at the same time serves to encourage the growth of other types of work. That is why it is said to be the basis. While nonbasis activity is activity which is endogenous meaning its growth depends on condition of economy of region as a whole, so that nonbasis activity is often called with service that is activity to fulfill requirement of society in area itself.

According to Hoover (1975), Bendavid-Val (1991), Isard et al. (1998), Stimson et al. (2006), Amstrong and Taylor (2007), and Hood, 1998 (in Hendayana, 2013), Location Quotient (LQ) is a simpler economic development tool with all its advantages and limitations. The LQ technique is one of the most common approaches used in the basis economic model as a first step to understanding the sector of activity that is driving growth. LQ measures the relative concentration or degree of specialization of economic activity through a comparative approach. The LQ technique measures the concentration of an activity (industry) within an area by comparing its role in the regional economy with the role of an activity or similar industry in a regional or national economy. LQ techniques can be divided into two, namely the static LQ (Static Location Quotient, SLQ) and dynamic LQ (Dynamic Location Quotient, 
DLQ). The LQ technique can help determine the export capacity of the regional economy and the degree of a sector. According to Suyatno (2000), the weakness of the LQ method is that this criterion is static which gives only a picture at a point in time. This means that the basis sector this year will not necessarily become the basis sector in the future, otherwise the non-basis sector at this time will probably become the basis sector in the future. The weakness of the LQ method can be overcome by the LQ variance, called Dynamic Location Quotient (DLQ), ie by introducing the growth rate assuming that each sectoral plus GDP has an average growth rate per year individually during the initial year and current year.

\section{Research Method}

\subsection{Research Location}

The research was conducted in Badung Regency of Bali Province, based on several considerations, namely (1) Badung Regency contribute greatly to the increase of GRDP of Bali Province; (2) Badung Regency is the center of tourism development in Bali Province and there are many cases of land conversion; and (3) The existence of inequality of development between regions that impact on the inequality of distribution of regional income.

\subsection{Data Collection}

Data collection using documentation method, that is looking at documents that are stored or published in several government agencies (see Sugiyono, 2013). Source of data is secondary source to dig secondary data, that is BPS of Bali Province and BPS of Badung Regency, covering data of GRDP of Bali Province and Badung Regency, data of population of Bali Province and Badung regency aged 15 years and above working according to business field, and data of GRDP growth rate of Bali Province and Badung Regency. The data used are time series data over the last five years ie data from 2011-2015 (see CBS Bali, 2015 and 2016; CBS Badung, 2016; 2016a, 2016b, 2016c, 2016d, 2016e, 2016d, and 2016f).

\subsection{Method of Data Analysis}

The method of data analysis is the Location Quotient (LQ) is used to determine the extent of the specialization of the basis sectors in a region's economic structure (See Hoover, 1975; Bendavid-Val, 1991; Azis, 1994; Isard et al., 1998; Stimson Et al., 2006; Baer and Brown, 2006; Amstrong and Taylor, 2007; Tarigan, 2007; Pendit, 2012; Baer and Brown, 2006), which in this research is Badung regency. Location Quotient (LQ) calculation formula as follows:

$$
L Q=\frac{X r / R V r}{X n / R V n}
$$

Information:

$\mathrm{Xr}$ : GRDP sector or GRDP of agriculture sub-sector in Badung regency

$\mathrm{RV}$ : Total GRDP or total GRDP of agriculture sector in Badung regency 


\section{Macrothink}

$\mathrm{Xn}$ : GRDP of sector or GRDP of agriculture sub sector in Bali Province

RVn : Total GRDP or total GRDP of agriculture sector in Bali Province

\section{Criteria:}

a) If LQ sector/sub-sector > 1, means sector/subsector is basis

b) If LQ sector/sub-sector $=1$, means the GRDP owned is consumed by the area

c) If LQ sector/sub-sector $<1$, means sector/sub-sector is non basis

The determination of sub-sectors basis or non-basis in the agricultural sector in the future in Badung Regency is used Dynamic Location Quotient (DLQ) method, with the following formula (see Herath, et al., 2011):

$$
D L Q=\left\{\frac{(1+g i j) /(1+g j)}{(1+G i) /(1+G)}\right\}^{t}
$$

\section{Information:}

gij : Average growth rate of agricultural subsector of Badung Rregency

gj : Average growth rate of Gross Regional Domestic Product (GRDP) of Badung Regency

Gi : Average growth rate of Bali's agricultural subsector

G : Average growth rate of GRDP of agriculture sector of Bali Province

$\mathrm{T}:$ the research period (five years from 2011-2015)

\section{Criteria:}

a) If DLQ $>1$, means the proportion of growth rate of sector i to regional GRDP is faster than the proportion of the same sector growth rate at the provincial level.

b) If DLQ $<1$, mean the proportion of growth rate of sector $i$ to regional GRDP is lower than the proportion of the same sector growth rate at the provincial level.

c) If $\mathrm{DLQ}=1$, means the proportion of growth rate of sector $\mathrm{i}$ to regional GRDP is equal to the proportion of the same sector growth rate at the provincial level (see Suyatno, 2000).

Changes in the positions of sub-sectors in the agricultural sector in Badung regency used a combined analysis of LQ and DLQ methods with the following criteria.

a) If the value of $L Q>1$ and DLQ $>1$, means that the agricultural sector/sub-sector remains the basis both in the present and in the future.

b) If the value of LQ $>1$ and DLQ $<1$, means the sector/sub-sector of agriculture has changed position from basis to non basis in the future.

c) If the value of LQ $<1$ and DLQ $>1$, means the sector/sub-sector of agriculture has changed from non basis to basis in the future. 


\section{Ml Macrothink}

d) If the value of LQ $<1$ and DLQ $<1$, means the agricultural sector/sub-sector remains non-basis both in the present and for the future.

Determination of factors causing the change of position of basis sector and non basis on sector and sub-sector of agriculture in Badung Regency used Shift Share analysis that is equal to Total Shift Share (TSS) can be described into two components namely Structural Shift Share (SSS) and Locational Shift Share (LSS), that can be used to determine the factors causing the change of position of basis sector and non basis on agriculture sector and sub sector in Badung regency. The formulas of Shift Share (see Hoover, 1975, Herzog and Olsen, 1977, Isard, 1998; Stimson et al., 2006; Amstrong and Taylor, 2007) are as follows:

$$
\begin{aligned}
S S S & =\sum\left(g_{n}-g_{\text {in }}\right) X_{\text {ino }}+\sum\left(G_{i}-G\right) X_{\text {ino }} \\
L S S & =\sum\left(g_{i n}-G_{i}\right) X_{\text {ino }} \\
T S S & =\sum\left(g_{n}-g_{\text {in }}\right) X_{\text {ino }}+\sum\left(G_{i}-G\right) X_{\text {ino }}+\sum\left(g_{i n}-G_{i}\right) X_{\text {ino }}
\end{aligned}
$$

Information:

$g_{n} \quad$ : Average growth rate (GRDP) total / GRDP of agriculture sector of Badung regency

$g_{\text {in }}$ : Average growth rate (GRDP) of sector / agricultura sub-sector of Badung Regency

$G_{i} \quad$ : Average growth rate (GRDP) of agriculture sector / sub-sector of Bali Province

G : Average growth rate (GRDP) of total / GRDP of agriculture sector of Bali Province

$X_{\text {ino }}:$ GRDP of agricultural sector / sub-sector of Badung Regency

Criteria:

a) If the value of SSS > LSS, means the most decisive factor on the occurrence of changes in agricultural sector and sub-sector in Badung regency is the factor of its economic structure.

b) If the value of SSS $<$ LSS, means the most decisive factor for the change of sector and subsector of agriculture in Badung regency is the location factor.

c) If the value of SSS = LSS, meaning factor of economic structure and location factor are equally strong in determining change of position of sector and sub sector of agriculture in Badung regency. 


\section{Result of Research and Discussion}

\subsection{Result of Basis Sector Identification}

Basis on the publication of BPS Badung (2015; 2016a; 2016b), the economic structure of Badung Regency is classified into 17 sectors. Result of basis and non basis sector identification to 17 sectors, found five sectors are basis sector, and 12 sector is non basis sector. The five basis sectors are water procurement, garbage processing, waste and recycling, construction sector, transportation and warehousing sectors, accommodation and feeding-drinking sector, and information and communications sector. These basis sectors are potentially developed as they are able to meet produces beyond local needs, so that their excess production can be exported to other areas.

Table 1. Basis Sector in Economic Structure of Badung Regency, Bali Province, Indonesia

\begin{tabular}{|c|c|c|c|c|c|c|c|c|}
\hline \multirow[t]{2}{*}{ No } & \multirow[t]{2}{*}{ Sectors } & \multicolumn{5}{|c|}{ LQ Value } & \multirow[t]{2}{*}{ Ave-rage } & \multirow[t]{2}{*}{ Infor-mation. } \\
\hline & & 2011 & 2012 & 2013 & 2014 & 2015 & & \\
\hline 1 & Agriculture, Forestry and Fisheries & 0.506 & 0.513 & 0.508 & 0.510 & 0.515 & 0.510 & Non basis \\
\hline 2 & Mining and excavation & 0.303 & 0.302 & 0.300 & 0.305 & 0.314 & 0.305 & Non basis \\
\hline 3 & Processing industry & 0.693 & 0.687 & 0.682 & 0.691 & 0.696 & 0.690 & Non basis \\
\hline 4 & Procurement of Electricity and Gas & 0.988 & 0.978 & 0.980 & 0.992 & 0.989 & 0.985 & Non basis \\
\hline 5 & $\begin{array}{l}\text { Water Supply, Waste Management, } \\
\text { Waste and Recycling }\end{array}$ & 1.347 & 1.338 & 1.337 & 1.350 & 1.368 & 1.348 & Basis \\
\hline 6 & Construction & 1.046 & 1.040 & 1.038 & 1.049 & 1.038 & 1.042 & Basis \\
\hline 7 & $\begin{array}{l}\text { Large and Retail Trade, Repair of } \\
\text { Cars and Motorcycles }\end{array}$ & 0.857 & 0.853 & 0.850 & 0.860 & 0.860 & 0.856 & Non basis \\
\hline 8 & Transportation and Warehousing & 2.561 & 2.540 & 2.521 & 2.441 & 2.393 & 2.491 & Basis \\
\hline 9 & $\begin{array}{l}\text { Provision of Accommodation and } \\
\text { Drinking }\end{array}$ & 1.323 & 1.318 & 1.323 & 1.329 & 1.343 & 1.327 & Basis \\
\hline 10 & Information and Communication & 1.178 & 1.173 & 1.170 & 1.182 & 1.167 & 1.174 & Basis \\
\hline 11 & Financial Services and Insurance & 0.694 & 0.688 & 0.688 & 0.704 & 0.716 & 0.698 & Non basis \\
\hline 12 & Real Estate & 0.836 & 0.832 & 0.830 & 0.840 & 0.858 & 0.839 & Non basis \\
\hline 13 & Company Services & 0.741 & 0.735 & 0.735 & 0.744 & 0.743 & 0.740 & Non basis \\
\hline 14 & $\begin{array}{l}\text { Government Administration, } \\
\text { Defense and Social Security }\end{array}$ & 0.677 & 0.673 & 0.671 & 0.680 & 0.687 & 0.677 & Non basis \\
\hline 15 & Educational Services & 0.689 & 0.683 & 0.683 & 0.692 & 0.686 & 0.687 & Non basis \\
\hline 16 & Health Services and Social Activities & 0.648 & 0.645 & 0.643 & 0.651 & 0.660 & 0.650 & Non basis \\
\hline 17 & Other services & 0.528 & 0.525 & 0.523 & 0.530 & 0.530 & 0.527 & Non basis \\
\hline
\end{tabular}

Information:

1) $\mathrm{LQ}<1 \rightarrow$ Non Basis

2) $\mathrm{LQ}=1 \rightarrow$ Domestic products have been consumed by the area.

3) $\mathrm{LQ}>1 \rightarrow$ Basis 


\section{Mll Macrothink}

Research in Applied Economics

ISSN 1948-5433

2017, Vol. 9, No. 3

The water procurement, garbage processing, waste and recycling sector with an average LQ of more than one of 1,348, it is means this sector in Badung Regency has a more prominent role than the same sector in Bali Province level. This is in line with the increasing number of residents and the number of tourists visiting and staying in the regency of Badung, which has an impact on the increase on the need for clean water and increasing the amount of waste. This sector includes activities related to the processing of various forms of waste or waste and the provision of clean water. The greatest added value provided by the water supply supported by community needs for clean water continues to increase. For waste processing, waste, and recycling can still be managed better with the help of the surrounding community is expected to be able to reduce waste production by being able to process the waste independently, so that later generated waste can provide benefits.

The construction sector is included in the basis sector with an average LQ of more than one of 1,042, meaning that the role of construction sector in Badung Regency is more prominent than the role of the same sector at the Bali Province level. This condition is supported by the development of physical infrastructure by local governments that can increase the added value of the construction sector. Development such as roads, bridges and irrigation water structures is mostly done by the local government in 2015. There are three mega project development, namely the construction of Bali Mandara Toll, Ngurah Rai Airport, and Dewa Ruci intersection Underpass conducted in 2012.

Transportation and warehousing sector with an average LQ value of more than one of 2,491, means that this sector has a more prominent role than the same sector role at the provincial level. This is due to the presence of Ngurah Rai Airport in Badung regency as one of the air transport that is often used by the community, especially the tourists who visit Bali. Recorded in 2015 the number of international arrivals to Ngurah Rai Airport is 25,846 aircraft with $4,233,240$ passengers and for international departures of 25,899 airplanes with 4,308,664 passengers, while for domestic arrivals it is 36,954 units with The number of passengers as much as 4,273,633 and for domestic departures of 36,902 units of aircraft and passengers of 4,192,679 people (BPS, 2016).

The development of tourism activities in Badung Regency has an impact on the need of increased transportation services to support tourist activities. In addition to air transport that is often used by tourists, land transportation services are widely used by tourists such as public transport, as well as transportation service providers such as travel travel and motorcycle and car rental. In 2015, an increase in the number of motor vehicles, the number of motor vehicles in the regency of Badung such as cars as many as 73,396 units, buses as many as 246 units and motorcycles as much as 384,074 units (CBS Bali, 2016).

The provision of accommodation and eating-drinking sectors is a basis sector with an average LQ of more than one of 1,327, meaning the role of accommodation and eating-drinking sector in Badung regency is more prominent than the role of the same sector at the Bali Province level. Badung regency as one of the world tourism destination is able to contribute greatly to the economy of Badung Regency and as the main sector in the economic movement of Badung regency. As a tourist destination, Badung regency able to provide 
facilities and good service in supporting tourism activities. The existence of Ngurah Rai Airport as the entrance of the arrival of the tourists makes the Badung regency as a strategic location to be accessed by tourists, especially the area of South Badung which caused many investors to build accommodation facilities in the region. In 2015 there are 168 star hotels in South Badung and 483 non-star hotels in Badung Regency (CBS Bali, 2015), with the number of accommodation built impacting the opening of employment, thus positively impacting the surrounding community.

The information and communication sector is the basis sector with an average LQ of more than one of 1,174, meaning that the role of information and communication sector in Badung Regency has a more prominent role than the role of the same sector in Bali Province level. The information and communication sector has a role to support the activities of economic activities and other activities. In the current conditions, the need for information and communication is very important role especially in telecommunication services. This is causing the needs of the community for telecommunication facilities has increased, recorded the number of telephone subscribers in the regency of Badung in 2014 as much as 53,686 customers to 59,053 subscribers in 2015 (CBS Badung, 2016).

Sectors with an average LQ value less than one are non-basis sectors, covering agriculture, forestry and plantation sectors, mining and quarrying sectors, manufacturing sector, electricity and gas procurement sector, large and retail trade sector, car and motorcycle repairs, the information and communication sector, the financial services and insurance sector, the education services sector, the corporate services sector, the real estate sector, the administrative sector, defense and social security, the health services and social services sector, and other services sector.

Sectors belonging to non-base sector in Badung regency have a smaller role than the same sector at Bali Province level. Means that the sector is only able to meet the demands of the local market and there is a tendency in meeting demand requiring supply from other regions. However, it does not mean that the non-base sector is left and abandoned, but developed again so as to increase the added value and later able to potentially become a leading sector.

\subsection{Result of Identification of Basis Subsector on Agricultural Sector}

The development of central Badung region is still basis on the agricultural sector in a broad sense because most of the people are still working on the agricultural sector. Basis on statistical data for Petang, Abiansemal and Mengwi District (see BPS Badung, 2016c, 2016d and 2016e), the percentage of workforce in 2015 in the primary sector is 72.71 percent, 46.32 percent and 39.67 percent. Thus there is a need for further analysis of the leading sub-sectors in the agricultural sector that can provide an overview of development planning in the agricultural sector. The results of identification of the leading subsector in the agricultural sector can be seen through Table 2 . 
Table 2. Basis Subsector of Agricultural Sector in Badung Regency, Bali Province, Indonesia

\begin{tabular}{|c|c|c|c|c|c|c|c|c|}
\hline \multirow{2}{*}{\multicolumn{2}{|c|}{$\begin{array}{l}\text { Agricultural, Forestry } \\
\text { and Fisheries Sector }\end{array}$}} & \multicolumn{5}{|c|}{ LQ Value } & \multirow{2}{*}{ Average } & \multirow{2}{*}{ Information } \\
\hline & & 2011 & 2012 & 2013 & 2014 & 2015 & & \\
\hline \multicolumn{9}{|c|}{ 1. Agriculture, Animal } \\
\hline & Husbandry, Hunting and & 1.241 & 1.232 & 1.237 & 1.254 & 1.240 & 1.241 & Basis \\
\hline \multicolumn{9}{|c|}{ Agricultural Services } \\
\hline & a. Food Crops & 1.278 & 1.258 & 1.261 & 1.278 & 1.291 & 1.273 & Basis \\
\hline & $\begin{array}{l}\text { b. Annual Horticultural } \\
\text { Crops }\end{array}$ & 1.058 & 1.042 & 1.047 & 1.057 & 1.098 & 1.060 & Basis \\
\hline & c. Annual Plantation & 0.101 & 0.099 & 0.099 & 0.100 & 0.097 & 0.099 & Non basis \\
\hline & $\begin{array}{l}\text { d. Perennial and other } \\
\text { Horticultural Plants }\end{array}$ & 1.114 & 1.097 & 1.101 & 1.112 & 1.087 & 1.102 & Basis \\
\hline & e. Perennial Plantation & 0.191 & 0.188 & 0.188 & 0.190 & 0.184 & 0.188 & Non basis \\
\hline & f. Animal husbandry & 1.627 & 1.603 & 1.608 & 1.620 & 1.634 & 1.618 & Basis \\
\hline & $\begin{array}{l}\text { g. Agricultural Service } \\
\text { and Hunting }\end{array}$ & 1.223 & 1.201 & 1.208 & 1.218 & 1.168 & 1.203 & Basis \\
\hline 2. & Forestry and Logging & 0.080 & 0.079 & 0.079 & 0.080 & 0.078 & 0.079 & Non basis \\
\hline 3. & Fishery & 0.391 & 0.384 & 0.387 & 0.391 & 0.404 & 0.392 & Non basis \\
\hline
\end{tabular}

Information:

1) LQ $<1 \rightarrow$ Non Basis

2) $\mathrm{LQ}=1 \rightarrow$ Domestic products have been consumed by the area.

3) $\mathrm{LQ}>1 \rightarrow$ Basis

Basis on the result of identification of basis sectors of Badung Regency (Table 1), agriculture, forestry and fishery sector included in non-basis sector, but after identification of subsector basis on agriculture sector (Table 2) identified six subsector of basis, that is agriculture, hunting and agricultural services with details of food crop sub-sub-sector, annual horticultural crop sub-sub-sector, perennial and other horticultural crops sub-sub-sector, animal husbandry sub-sub-sector, and sub-sector of agricultural and hunting services.

The agricultural, animal husbandry, hunting and agricultural services sub-sectors are the basis sectors with an average LQ of 1,241, meaning that the agricultural, livestock, hunting subsectors are more prominent than the same subsector at the Bali Province level (Table 2). These sub-sectors have a comparative advantage supported by the geographical conditions of Badung and Central Badung which are suitable for agricultural activities in a broad sense. In addition, contributions from each sub-sub-sector of agriculture, livestock, hunting, and agricultural services consist of seven sub subsectors that can provide added value, so that the sub-sector of agriculture, livestock, hunting, and agricultural services are included into the basis sector.

The fisheries sub-sector is a non-basis sector with an average LQ of 0.392, meaning that the role of the fisheries subsector has a smaller role than the same subsector at the Bali Province 
level (Table 2). The southern boundary of Badung Regency is the sea that has potential to be developed fishery sub sector, but the role of fishery subsector fluctuation and tend to decrease in year 2015 compared to previous year. The condition is due to various obstacles faced ie natural conditions or unpredictable weather impact on the decrease of catches of fishermen.

\subsection{Result of Dynamic Identification of Basis Subsector on Agricultural Sector}

According to Suyatno (2000), the weakness of the LQ method is that this criterion is static which gives only a picture at a point in time. This means that the basis sector this year will not necessarily become the basis sector in the future, otherwise the non-basis sector at this time will probably become the basis sector in the future. The weakness of the LQ method can be solved using Dynamic Location Quotient (DLQ), ie by introducing the growth rate assuming that each sectoral plus GDP has an average growth rate per year individually during the period of the initial year and the current year.

Based on the results of the calculation of DLQ (Table 3) it is known that in agriculture, forestry, and fishery sub-sectors become basis are the sub-sub-sector of food crops, sub-sub-sector of annual horticultural crops, and fishery sub-sector. Non-basis sub-sectors include agriculture, livestock, hunting and agricultural services sub-sectors, annual plantation sub-sector sub-sectors, annual and other horticultural crops sub-sub-sector, perennial plantation sub-sub-sector, animal husbandry sub-sub-sector, agriculture services and hunting sub-sub-sector, and forestry and logging sub-sub-sector.

Table 3. Dynamic Location Quotient and Changes in Agriculture, Forestry and Fisheries Sub-Sector in Economic Structure of Badung Regency, Bali Province

\begin{tabular}{lccl}
\hline \multicolumn{1}{c}{ Subsector of Agriculture, Forestry, and Fisheries } & LQ & DLQ & \multicolumn{1}{c}{ Change } \\
\hline 1. Agriculture, Animal Husbandry, Hunting and Agricultural Services & 1.241 & 0.94 & Basis $\rightarrow$ Non Basis \\
a. Food Crops & 1.273 & 5.51 & Fixed Basis \\
b. Annual Horticultural Crops & 1.060 & 12.28 & Fixed Basis \\
c. Annual Plantation & 0.099 & 0.38 & Fixed Non Basis \\
d. Annual and other Horticultural Crops & 1.102 & 0.49 & Basis $\rightarrow$ Non Basis \\
e. Perennial Plantation & 0.188 & 0.37 & Fixed Non Basis \\
f. Animal husbandry & 1.618 & 0.90 & Basis $\rightarrow$ Non Basis \\
g. Agricultural Services and Hunting & 1.203 & 0.28 & Basis $\rightarrow$ Non Basis \\
2. Forestry and Logging & 0.079 & 0.58 & Fixed Non Basis \\
3. Fishery & 0.392 & 1.76 & Non Basis $\rightarrow$ Basis \\
\hline
\end{tabular}

Basis on the merging of the two LQ and DLQ analyzes (Table 3), five sub-sectors change of roles, namely agriculture, livestock, hunting and agricultural services sub-sectors, annual horticultural and other sub-sub-sectors, animal husbandry sub-sub-sector, agricultural service and hunting sub-sub-sector, and Fisheries subsector. While for the sub-sector non-changing role include the sub-sector of fixed basis are food crops sub-sub-sector and the sub-sub-sector of annual horticultural crops, while for the non-basis sector are the sub-sub-sectors of annual 
plantations, the sub-sectors of perennial plantations, and the forestry and logging sub-sectors.

Based on the merging of both LQ and DLQ analyzes, five sub-sectors of agriculture, forestry and fisheries are affected. These sub-sectors include agriculture, livestock, hunting, and agricultural services sub-sectors, horticultural subsectors and other sub-sectors, livestock sub-sub-sector, agriculture and hunting sub-sector sub-sector, and fishery sub-sector. The non-sub-sector sub-sector of horticultural crops, for the non-base sectors are sub plantation sub-sector, annual estate sub-sector sub-sector, and forestry and logging sub-sector.

\subsection{Factors Cause of Changes in the Basis Subsector on Agricultural Sector}

According to Suyatno (2000), the LQ and DLQ methods only show the sectoral position and reposition in regional economic growth without addressing the cause of the change. Understanding to know the factors causing sectoral repositioning is very important because it is the key to know the ability of the region to maintain the basis sector. Therefore, to know the cause of change is used Total Shift Share analysis (TSS) consisting of Structural Shift Share (SSS) and Location Shift Share (LSS). The results of Total Shift Share Analysis of Agriculture, Forestry, and Fisheries Sub-sector of Badung Regency, Bali Province are presented in Table 4.

Table 4. Structural Shift Share and Location Shift Share of Agriculture, Forestry, and Fishery Sub-sector of Badung Regency, Bali Province

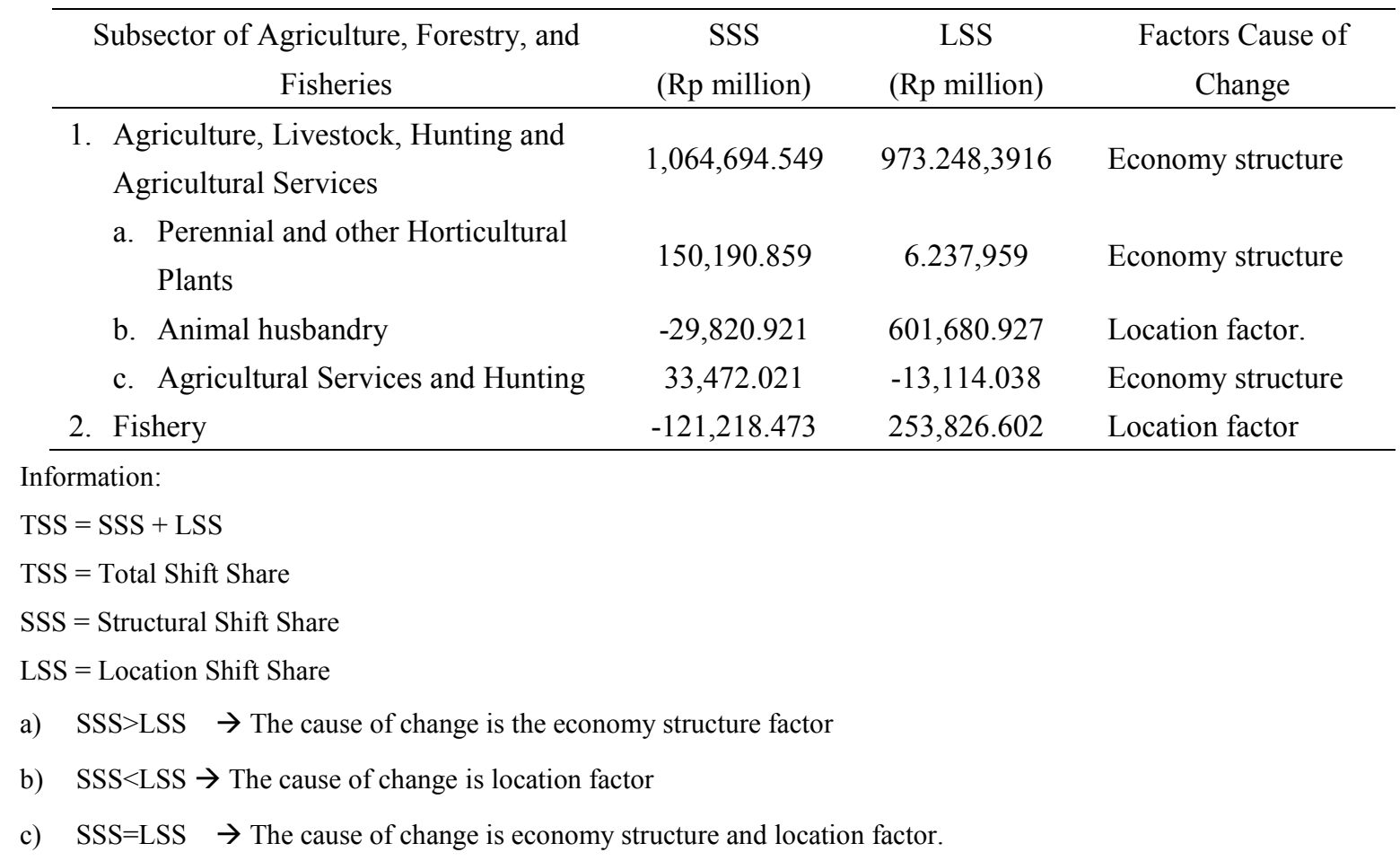

There are two factors causing the change of agriculture, forestry and fishery sub sector position in economic structure of Badung Regency. The economic structure is the cause of the change in the role of agriculture, hunting and hunting sub-sector, horticulture 
sub-sub-sector, and agriculture and hunting sub-sector. While the location factor is the cause of the change of livestock sub-sub-sector and fishery sub-sector.

There are two causes of changes in the position of agricultural sub-sector, forestry, and fishery in the economic structure of Badung Regency. The economic structure is the cause of the change in the role of agriculture, hunting and hunting sub-sector, horticulture sub-sub-sector, and agriculture and hunting sub-sector. While the location factor is the cause of the change of livestock sub-sub-sector and fishery sub-sector.

Subsector of agriculture, animal husbandry, and hunting services with value of SSS value of Rp 1,064,694,549 million and LSS value of Rp 973,248,3916 million. This value indicates that the value of SSS is bigger than the value of LSS, so that the change of role of sub sector of agriculture, livestock, and hunting service from base sector in the present to non-base sector in the future is caused by economic structure factor in Badung regency. Changes caused by economic structure factor can be seen from contribution of agriculture sector to GRDP of Badung Regency continues to decrease and growth of tourism which impact to shift of economic structure from primary sector to secondary sector and tertiary sector.

Structure of the economy that is more directed to the tertiary sector one of them is tourism as a cornerstone of the economy of Badung regency. This has an impact on the community began to switch to the tertiary sector of the primary sector before, so that the declining interest of the community to do agricultural activities. Declining productivity and decreasing number of farmers, and decreasing the amount of agricultural land have a major impact on the small contribution of agriculture sub-sector, farming, hunting, and agricultural services to PDRB of Badung Regency.

Sub-sectors of perennial horticultural crops and others with SSS value of Rp 150,190,859 million and LSS value of Rp 6,237,959 million, the value indicates that the value of SSS is greater than the value of LSS which means that the role change from the base sector in the present to be Non-base sector in the future caused by economic structure factor in Badung regency.

Livestock sub-sub-sector experienced a change in the role of the base sector in the present into the nonbased sector in the future. The cause of this role change can be seen from the value of SSS and LSS with SSS value of Rp -29,820,9206 million and LSS value of Rp $601,680,9274$ million, this value indicates that LSS value is bigger than LSS value, so the factors that cause the occurrence The change of livestock sub-sub-sector role is location factor. All areas of Badung Regency have potential to be developed for livestock sector, the most developed cattle are cattle, pigs, and poultry. However, the decrease in the number of livestock is caused by the decreasing of land that occurs in Badung regency, so that the effect on the change of livestock sub-sub-sector role as a whole and in the future can not be relied upon to become the base sector.

Sub-sectors of services agricultural and hunting with SSS value of Rp 33.472 .0208 million and LSS value of Rp -13,114,038 million, the value indicates that the value of SSS is greater than the value of LSS which means that the change in the role of sub-subsector agricultural 
services and hunting From the base sector in the present into the non-base sector in the future caused by the economic structure of Badung Regency. Changes caused by economic structural factors can be seen from the contribution of the agricultural sector to PDRB Badung regency continues to decline and the rapid growth of tourism. Structure of the economy as a factor causing the change in the role of sub-sub-sector of agricultural services and hunting due to the growing tourism impact on the reduction of productive land. The reduction of the land causes the need for agricultural services to decrease because of the land cultivated a little and does not require assistance or agricultural services are many, so the added value produced decreases.

Fisheries sub-sector with SSS value of Rp -121,218,473 million and LSS value of Rp $253,826,6016$ million, this value indicates that the change of role of fishery sub-sector from non-base sector at present to base sector in the future is caused by location factor. The regency of Badung Regency with the most activities of the fishery sub-sector is South Badung which directly adjacent to the sea, so the location is able to contribute significantly to the increase of fishery sector catch.

The condition is able to provide opportunities for the South Badung region in increasing the production of marine fish. The advantage of location owned by Badung regency can increase the interest of the surrounding community in fishing activities. Various types of fish produced able to meet the local market and is expected to conduct import activities, so as to increase the added value of fishery sub-sector to GRDP of Badung regency.

\section{Conclusions and Policy Recommendations}

\subsection{Conclusion}

1. Potential basis sector developed in Badung regency are water supply, waste treatment, waste and recycling sector, construction sector, transportation and warehouse sector, accommodation and eating-drinking sector, information and communications sector.

2. Agricultural sub-sectors that are the basis sub-sectors include agriculture, livestock, hunting and agricultural services sub-sectors, food crop sub-sub-sector, horticultural crop sub-sub-sector, perennial horticulture crops and other sub-sub-sector, animal husbandry sub-sub-sector and agriculture and hunting sub-sub-sector.

3. The agricultural sub-sector has three sub-sub-sectors that are able to become the basis sub-sub-sector in the future are food crop sub-sub-sectors, horticultural crop sub-sub-sectors, and fishery sub-sectors.

4. Factors causing changes in the role of several agricultural sub-sectors from the basis sector to non-basis sector include agriculture, farming, hunting and agricultural services sub-sector, perennial horticulture and other crops sub-sector, and sub-sector of agricultural and hunting services caused by economic structure factor and animal husbandry sub-sector caused by location factor. The change of roles from non-basis sector to basis caused by location factor is fishery sub-sector. 


\section{Macrothink}

\subsection{Policy Recommendations}

1. In the regional development planning, the government of Badung Regency is expected to prioritize the development of identified basis sector, so as to optimize the potential of the resources owned

2. The non-basis sector, especially the agricultural sector, is more concerned with development planning, because the agricultural sector in Badung regency, as well as the source of livelihood for the population of North an Central Badung region, as well as food supply of South Badung.

\section{Acknowledgement}

Thank you to the leaders and staff of the Central Bureau of Statistics of Bali Province and Badung Regency, Regional Development Planning Board of Bali Province and Badung regency for the willingness to serve us in collecting data. May His good deeds be rewarded by the God.

\section{References}

Amstrong, H., \& Taylor, J. (2007). Regional Economics and Policy(3rd Ed.). Australia: Balackwell Publishing.

Azis, Iwan J. (1994). Regional Economics and its Application in Indonesia. Editor: Marsudi Djojodipuro. Agency Publisher of Economics Faculty, University of Indonesia, Jakarta.

Badungkab. (2017). Featured Sector. Retrieved February 6, 2017 from: http://www.badungkab.go.id/menu/5/ sectorus

Baer, C., \& Brown, T. (2006). Location Quotients: A Tool for Comparing Regional Industry Compositions. In Context. A publication of the Indiana Business Research Center at IU's Kelley School of Business. March 2006, 7(3), 1-3.

Bendavid-Val, Avrom. (1991). Regional and Local Economic Analysis for Practitioners (4 ${ }^{\text {th }}$ Ed.). London: Praeger Publisher.

CBS Bali. (2015). Bali In Figures 2016. Published by Bali Central Bureau of Statistics.

CBS Bali. (2016). Bali In Numeric 2016. Published by Bali Central Bureau of Statistics.

CBS Badung. (2015). Badung Regency In Numeric 2015. Published by Central Agency Statisti Badung regency.

CBS Badung. (2016a). Badung Regency In Numeric 2015. Published by Central Agency Statisti Badung regency.

CBS Badung. (2016b). Gross Regional Domestic Product of Badung Regency Basis of Sectors 2011-2015. Published by Statistic Central Agency of Badung Regency. 


\section{I Macrothink}

CBS Badung. (2016c). Statistics of Petang Districts 2016 of Badung Regency. Published by Statistic Central Agency of Badung Regency.

CBS Badung. (2016d). Statistic of Abiansemal District 2016 of Badung regency. Publishedd by Statistic Central Agency of Badung Regency.

CBS Badung. (2016e). Statistics of Mengwi District 2016 of Badung Regency. Published by Statistic Central Agency of Badung Regency.

CBS Badung. (2016f). Statistics of Kuta District 2016 of Badung Regency. Published by Statistic Central Agency of Badung Regency.

Erawati, K. (2012). Analysis of Economic Growth Pattern and Potential Sector of Klungkung Regency. E-Journal of Development Economics Unud, 1 (1), pp: 41-61.

Hastutiningsih, Y. (2010). Development of District Based of Agricultural Commodity in Sragen Regency. Agricultural Socio Economic Study Program, Faculty of Agriculture, Sebelas Maret University. Surakarta.

Hendayana, R. (2003). Application of Location Quotient (LQ) Method in Determination of National Superior Commodities. Bogor Agricultural Technology Research and Development Center.

Herath, J., Gebremedhindan, T.G., \& Maumbe, B.M. (2011). A Dynamic Shift Share Analysiis of Economic Growth in West Virginia. Journal of Rural and Community Development, 6(2), 134-145.

Herzog, H.W., \& R. Olsen. (1977). Shift-Share Analysis Revisited: The Allocation Effect and The Stability of Regional Structure. Tenesse: OAK Ridge National Laboratory. https://doi.org/10.2172/7301712

Hoover, E.M. (1975). An Antroduction to Regional Economics (2nd Ed.). New York: Alfred A. Knopt Publisher.

Isard, W. Azis, I.J., Drennan, M.O., Miller, R.E., Saltsman, S., \& Thorbecke, E. (1998). Methods of Interregional and Regional Analysis. Published by Ashagate Publishing Limited, England.

Pendit, P. (2012). Determination of Potential Economic Sectors in Order to Support Economic Development Planning in Bangli District. [Thesis]. Master Program of Economics Program of Graduate Program of Udayana University. Denpasar, Bali,Indonesia.

Richardson, H. W. (2001). Dasar=Dasar Ilmu Ekonomi Regional. Edisi Revisi (Penterjemah: Paul Sitohang). Jakarta: Lembaga Penerbit Fakultas Ekonomi Universitas Indonesia.

Stimson, R.J., Stough, R.R., \& Roberts, B.H. (2006). Regional Economic Development, Analysis and Planning Strategy(2nd Ed.). BerlinHeidelberg: Springer-Verlag Publishing. 


\section{Macrothink}

Sugiyono. (2013). Metode Penelitian Bisnis (Pendekatan Kuantitatif, Kualitatif, dan R\&D). Bandung: Alfabeta Publisher.

Sukirno, S. (2002). Introduction to Macroeconomics Theory. Jakarta: PT Raja Grafindo Persada.

Suyatno. (2000). Economic Basis Analysis on Economic Growth in Wonogiri Second Level Region: Facing the Implementation of Law no. 22/1999 and Law no. 5/1999. Journal of Development Economics Vol. I No.2, December 2000: 144-159. Faculty of Economics, University of Muhammadiyah Surakarta. Surakarta.

Tarigan, R. (2005). Regional Economics Theory and Applications. Jakarta: Bumi Aksara Publisher.

Todaro, M.P. (1999). Economic Development 'in the Third World (6th Ed.). Jakarta: Erlangga Publisher.

\section{Copyright Disclaimer}

Copyright for this article is retained by the author(s), with first publication rights granted to the journal.

This is an open-access article distributed under the terms and conditions of the Creative Commons Attribution license (http://creativecommons.org/licenses/by/3.0/). 